\title{
Abbreviations and Conventions
}

For this volume personal names and place names have been modernised where identified. Personal names conform in general to G. S. Black, The Surnames of Scotland (New York, I946). Place names have been modernised according to the Ordnance Survey Gazetteer of Great Britain (London, 1987). Sums of money are in pounds Scots unless otherwise stated (the pound Scots being worth roughly half a pound sterling before $c .1450$, and roughly a third thereafter, falling to a quarter by the late ${ }_{5} 560$ and then to a fixed rate of twelve pounds Scots to the pound sterling from i6or onwards). The letters thorn and yogh are represented by th and $y$ (except where $z$ is the normal form) respectively. Dates have been modernised with the year change on I January rather than on 25 March.

With the exception of those abbreviations given below, sources are cited in full when first mentioned in individual chapters and then given in abbreviated form thereafter in each chapter.

$A P S$

Acts of the Parliaments of Scotland, T. Thomson and

C. Innes (eds) (I2 vols, Edinburgh, I8I4-75).

Brown and Tanner

K. M. Brown and R. Tanner (eds), The History of the (eds), Parliament Scottish Parliament Volume I: Parliament and Politics and Politics in in Scotland I235-1560 (Edinburgh, 2004).

Scotland I235-I560

Brown and Mann

K. M. Brown and A. J. Mann (eds), The History of (eds), Parliament the Scottish Parliament Volume 2: Parliament and and Politics Politics in Scotland 1567-I707 (Edinburgh, 2005).

in Scotland, I567-I707

Calderwood, History

History of the Kirk of Scotland by Mr David Calderwood, T. Thomson (ed.) (8 vols, Wodrow Society, I842-9). 
$C D S$

CSP Scot

EHR

ER

$H M C$

NAS

NLS

$\operatorname{NRA}(S)$

PER

Rait, Parliaments

$R C R B S$

$R M S$

$R P C$

RPS

$R R S$

RSCHS

Scots Peerage
Calendar of Documents Relating to Scotland Preserved, J. Bain (ed.) (5 vols, Edinburgh, I88I-8).

Calendar of State Papers Relating to Scotland and Mary, Queen of Scots, I547-I603, J. Bain, W. K. Boyd and A. I. Cameron (eds) (Edinburgh, I 888-I969).

English Historical Reviem.

The Exchequer Rolls of Scotland, J. Stuart et al. (eds) (23 vols, Edinburgh, I878-1906).

Historical Manuscripts Commission.

National Archives of Scotland (formerly the Scottish Record Office), Edinburgh.

National Library of Scotland, Edinburgh.

National Register of Archives (Scotland).

Parliaments, Estates and Representation.

R. S. Rait, The Parliaments of Scotland (Glasgow, 1924).

Extracts from the Records of the Convention of Royal Burghs of Scotland, I295-I738, J. D. Marwick (ed.) (5 vols, Edinburgh, I 867-85).

Registrum Magni Sigilli Regum Scotorum, J. M. Thomson et al. (eds) (Edinburgh, I882-I9I4).

Register of the Privy Council of Scotland (37 vols over three series, I545-I69I).

The Records of the Parliaments of Scotland to I707, K. M. Brown et al. (eds) (St Andrews, 2007- ). Accessed between November 2007 and November 2009.

Regesta Regum Scottorum, G. W. S. Barrow et al. (eds) (Edinburgh, I96o- ).

Records of the Scottish Church History Society.

The Scots Peerage, J. B. Paul (ed.) (9 vols, Edinburgh, I904-I4). 
SHR

SHS

Tanner, Parliament

Terry, Scottish

Parliament

TRHS

Young,

Commissioners

Young, Scottish

Parliament
Scottish Historical Reviem.

Scottish History Society.

R. Tanner, The Late Medieval Scottish Parliament:

Politics and the Three Estates, I424-I488 (East Linton, 200I).

C. S. Terry, The Scottish Parliament: Its Constitution and Procedure I603-I707 (Glasgow, I905).

Transactions of the Royal Historical Society.

M. Young (ed.), The Parliaments of Scotland. Burgh and Shire Commissioners (2 vols, Edinburgh, 1992-3).

J. R. Young, The Scottish Parliament I639-I66I: A Political and Constitutional Analysis (Edinburgh, I996). 